\title{
Failure to replicate an association of SNPs in the oxidized LDL receptor gene (OLRI) with CAD
}

Joshua W Knowles $^{\dagger 1}$, Themistocles L Assimes ${ }^{\dagger 1}$, Eric Boerwinkle ${ }^{7}$, Stephen P Fortmann ${ }^{6}$, Alan Go ${ }^{5}$, Megan L Grove ${ }^{7}$, Mark Hlatky ${ }^{1,2}$, Carlos Iribarren ${ }^{5}$, Jun $\mathrm{Li}^{3}$, Richard Myers ${ }^{3}$, Neil Risch ${ }^{4,5}, 8$, Stephen Sidney ${ }^{5}$, Audrey Southwick ${ }^{3}$, Kelly A Volcik ${ }^{7}$ and Thomas Quertermous*1

\author{
Address: ${ }^{1}$ Division of Cardiovascular Medicine, Falk Cardiovascular Research Building, Stanford University School of Medicine, Stanford, CA, \\ 94305-5406, USA, ${ }^{2}$ Department of Health Research and Policy, Redwood Building, Stanford University School of Medicine, Stanford, CA 94305, \\ USA, ${ }^{3}$ Stanford Human Genome Center, Department of Genetics, Stanford University School of Medicine, 975 California Ave, Palo Alto, CA, \\ 94304, USA, ${ }^{4}$ Institute for Human Genetics, University of California San Francisco, San Francisco, 94143, USA, ${ }^{5}$ Division of Research, Kaiser \\ Permanente of Northern California, Oakland, CA, 94612, USA, ${ }^{6}$ Stanford Prevention Research Center, Stanford University School of Medicine, \\ Stanford, CA 94305-5705, USA, ${ }^{7}$ Human Genetics Center, University of Texas Houston Health Science Center, 1200 Herman Pressler Dr., \\ Houston, TX, 77030, USA and ${ }^{8}$ Departments of Epidemiology, Biostatistics and Medicine, University of California, San Francisco, USA \\ Email: Joshua W Knowles - knowlej@stanford.edu; Themistocles L Assimes - tassimes@cvmed.stanford.edu; \\ Eric Boerwinkle - Eric.Boerwinkle@uth.tmc.edu; Stephen P Fortmann - Fortmann@stanford.edu; Alan Go - Alan.S.Go@kp.org; \\ Megan L Grove - Megan.L.Grove@uth.tmc.edu; Mark Hlatky - mah@stanford.edu; Carlos Iribarren - Carlos.Iribarren@kp.org; \\ Jun Li - junzli@umich.edu; Richard Myers - myers@paxil.stanford.edu; Neil Risch - rischn@humgen.ucsf.edu; \\ Stephen Sidney - Steve.Sidney@kp.org; Audrey Southwick - southwic@stanfordalumni.org; Kelly A Volcik - Kelly.A.Volcik@uth.tmc.edu; \\ Thomas Quertermous* - tomq1@stanford.edu \\ * Corresponding author †Equal contributors
}

Published: 2 April 2008

BMC Medical Genetics 2008, 9:23 doi:10.1 186/147/-2350-9-23
Received: 22 January 2008

Accepted: 2 April 2008

This article is available from: http://www.biomedcentral.com/I47I-2350/9/23

(c) 2008 Knowles et al; licensee BioMed Central Ltd.

This is an Open Access article distributed under the terms of the Creative Commons Attribution License (http://creativecommons.org/licenses/by/2.0), which permits unrestricted use, distribution, and reproduction in any medium, provided the original work is properly cited.

\begin{abstract}
Background: The lectin-like oxidized LDL receptor LOX-I (encoded by OLRI) is believed to play a key role in atherogenesis and some reports suggest an association of OLRI polymorphisms with myocardial infarction (MI). We tested whether single nucleotide polymorphisms (SNPs) in OLRI are associated with clinically significant CAD in the Atherosclerotic Disease, VAscular FuNction, \& Geneti C Epidemiology (ADVANCE) study.
\end{abstract}

Methods: ADVANCE is a population-based case-control study of subjects receiving care within Kaiser Permanente of Northern California including a subset of participants of the Coronary Artery Risk Development in Young Adults (CARDIA) study. We first resequenced the promoter, exonic, and splice site regions of OLRI and then genotyped four single nucleotide polymorphisms (SNPs), including a non-synonymous SNP (rsII053646, LysI67Asn) as well as an intronic SNP (rs3736232) previously associated with CAD.

Results: In I,809 cases with clinical CAD and I,734 controls, the minor allele of the coding SNP was nominally associated with a lower odds ratio $(O R)$ of $C A D$ across all ethnic groups studied (minimally adjusted $O R=0.8, P=0.007$; fully adjusted OR 0.8, $P=0.01$ ). The intronic SNP was nominally associated with an increased risk of CAD (minimally adjusted OR I.I2, $P=0.03$; fully adjusted $O R \quad I .13, P=0.03$ ). However, these associations were not replicated in over 13,200 individuals (including I,470 cases) in the Atherosclerosis Risk in Communities (ARIC) study.

Conclusion: Our results do not support the presence of an association between selected common SNPs in OLRI and the risk of clinical CAD. 


\section{Background}

Oxidized LDL (oxLDL) is thought to play a crucial role in the initiation of atherosclerotic lesions. The lectin-like oxidized LDL receptor (LOX-1) is expressed on endothelial cells, macrophages and vascular smooth muscle cells and specifically binds and internalizes oxLDL leading to pleotropic effects on endothelial dysfunction and atherosclerosis. LOX-1 was originally identified by Sawamura et al [1] and was later localized to chromosome 12. The human gene spans six exons and encodes a protein of 273 amino acids with four distinct domains: an N-terminal cytoplasmic domain crucial for cell sorting, a transmembrane domain, a neck domain with homology to the myosin heavy chain, and a C-terminal lectin-like domain (CTLD) which is responsible for binding oxLDL [2-5] (Figure 1). In vitro, oxLDL binding to LOX-1 results in increased expression of cellular adhesion molecules, inflammatory mediators and activation of pro-apoptotic pathways [6-10]. In vivo, LOX-1 is found at high concentrations in human atherosclerotic lesions and overexpression of LOX-1 in apolipoprotein E -/- mice results in increased cholesterol deposition in coronary arteries $[11,12]$.

Human association studies to date have been conflicting regarding whether polymorphisms in this gene are associated with CAD and/or its complications [13-21]. As part of the overall goals of the Atherosclerotic Disease, VAscular FuNction, \& Geneti $C$ Epidemiology (ADVANCE) study at Stanford University and Kaiser Permanente of Northern California (KPNC), we sought to test whether SNPs in the LOX-1 gene, ORL1, alter susceptibility to $\mathrm{CAD}$. We also sought to replicate any putative genotype-

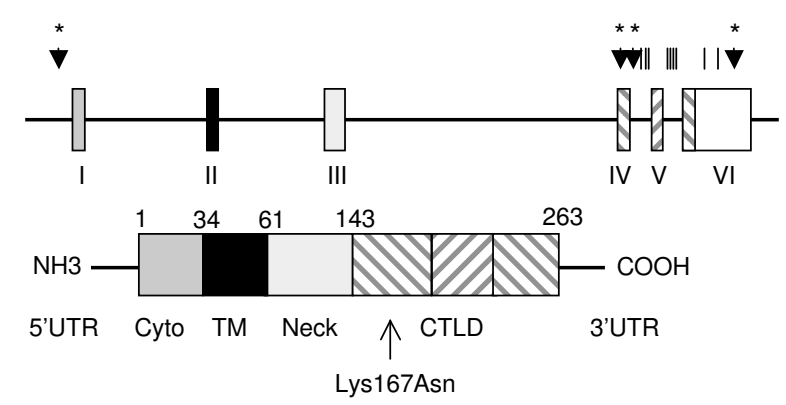

\section{Figure I}

Structure of LOX-I gene and protein. Upper drawing: Rectangles represent exons, with tic marks \& arrows designating location of sequenced SNPs and genotyped SNPs in the ADVANCE study respectively. Lower drawing: Schematic of the protein structure of LOX-I. The arrow shows the position of LOX I.2 SNP, and the resultant amino acid change. phenotype associations in an independent and well characterized cohort as replication is now considered the gold standard method to validate such associations $[22,16,23-$ 27]. We selected the National, Heart, Lung, and Blood Institute's Atherosclerosis Risk in Communities (ARIC) study to serve as our replication cohort because the primary outcome of interest in that study of incident coronary heart disease (CHD) was the same as the ADVANCE study and was diligently adjudicated.

\section{Methods \\ Study Sample ADVANCE}

The ADVANCE study included adults (age $\geq 18$ years) receiving medical care within KPNC. Detailed description of the eligibility criteria and the source population for all cohorts, have been published previously [28-30]. The design of ADVANCE allowed for several primary case control comparisons (see study website for details[31]). Between October 28, 2001 and December 31, 2003, we recruited a total of 3179 case and control subjects. Cases consisted subjects presenting with clinically significant CAD (myocardial infarction or angina with angiogram showing at least one $>50 \%$ stenosis $)$ at a young age $(<45$ years for males, $<55$ years for females) or subjects presenting with incident stable angina or incident acute myocardial infarction (AMI) at an older age. Controls consisted of young subjects with no history of CAD including a subset of 479 subjects from the Coronary Artery Risk Development in Young Adults (CARDIA) Study [32], or subjects aged 60 to 72 with no history of CAD, cerebrovascular accident (CVA), or peripheral arterial disease (PAD). During recruitment, some race/ethnic and gender strata were oversampled to maximize the probability that case and control groups were balanced in these respects. In this study, we focused on a combined analysis comparing subjects with symptomatic early onset CAD ("young cases") with young subjects without CAD ("young controls") and older subjects presenting with stable angina or AMI ("older cases") with older subjects with no history of CAD, CVA, or PAD ("older controls") (Table 1).

\section{Clinical Measurements}

Through a phone interview, an extensive self administered questionnaire, and the use of the KPNC electronic databases, we documented the presence or absence and age of onset of clinically significant CAD, CVA, and PAD, as well as all traditional risk factors for atherosclerosis. Subjects also provided information on race/ethnicity and were classified into one of nine race/ethnic groups: white/Europeans, black/African Americans, Hispanics, South Asians, East Asians, Pacific Islanders, Native Americans, admixed Hispanics, and admixed non-Hispanics. At the clinic visit, we measured the height and weight of all participants and collected whole blood for DNA extraction and quantification of various serum markers. For this study, traditional 
Table I: Non-genetic characteristics of the ADVANCE study according to case/control status (symptomatic CAD) stratified by two primary predefined comparisons

\begin{tabular}{|c|c|c|c|c|c|c|}
\hline & $\begin{array}{c}\text { Young Cases }(n= \\
472)\end{array}$ & $\begin{array}{l}\text { Young Controls ( } \mathrm{n} \\
=742)\end{array}$ & $\mathbf{P}$ & $\begin{array}{c}\text { Older Cases }(n= \\
\text { I337) }\end{array}$ & $\begin{array}{l}\text { Older Controls (n } \\
=992)\end{array}$ & $\mathbf{P}$ \\
\hline & Mean(SD) & Mean(SD) & $\mathbf{T}$ test & Mean(SD) & Mean(SD) & $T$ test \\
\hline \multirow[t]{2}{*}{ Age(years) * } & $45.3(6.5)$ & $44.3(5.5)$ & 0.005 & $62(8.4)$ & $65.8(2.9)$ & $<0.001$ \\
\hline & Median (Range) & Median (Range) & Wilcoxon & Median (Range) & Median (Range) & Wilcoxon \\
\hline Body Mass Index & $31.1(|7.3-6| .2)$ & $26.8(15.8-66.2)$ & $<0.001$ & $28.4(16.9-66.1)$ & $27.5(17.3-52.9)$ & $<0.001$ \\
\hline C-Reactive Protein & $2.3(0.1-76.4)$ & $1.2(0.1-76.8)$ & $<0.001$ & $1.7(0.1-77.4)$ & $1.6(0.1-73.9)$ & 0.163 \\
\hline \multirow{2}{*}{$\begin{array}{l}\text { Months from first ever } \\
\text { event to study visit }\end{array}$} & $21.3(2.7-222.1) \dagger$ & -- & -- & $3.5(1.4-26.4) \dagger$ & -- & -- \\
\hline & Count(\%) & Count(\%) & $\mathrm{Chi}^{2}$ & Count(\%) & Count(\%) & $\mathrm{Chi}^{2}$ \\
\hline \multicolumn{7}{|l|}{$\begin{array}{l}\text { Risk Factors (Self } \\
\text { Report) }\end{array}$} \\
\hline Male & 184(39) & $328(44.2)$ & 0.072 & $975(72.9)$ & $618(62.3)$ & $<0.001$ \\
\hline $\begin{array}{l}\text { Current/Former } \\
\text { smoker }\end{array}$ & $276(58.5)$ & $266(35.8)$ & $<0.001$ & $842(63)$ & $569(57.4)$ & 0.006 \\
\hline Hypertension & $154(32.6)$ & $143(19.3)$ & $<0.001$ & $64 I(47.9)$ & $407(4 I)$ & $<0.001$ \\
\hline Diabetes Mellitus & $101(21.4)$ & $5 I(6.9)$ & $<0.001$ & $274(20.5)$ & $147(\mid 4.8)$ & $<0.001$ \\
\hline High Cholesterol & $129(27.3)$ & $148(19.9)$ & 0.003 & $604(45.2)$ & $356(35.9)$ & $<0.001$ \\
\hline Ancestry & & & $<0.001$ & & & $<0.001$ \\
\hline White/European & $254(53.8)$ & $369(49.7)$ & & $947(70.8)$ & $677(68.2)$ & \\
\hline $\begin{array}{l}\text { Black/African } \\
\text { American }\end{array}$ & $46(9.7)$ & $254(34.2)$ & & $50(3.7)$ & $79(8)$ & \\
\hline Hispanic & $25(5.3)$ & $22(3)$ & & $83(6.2)$ & $60(6)$ & \\
\hline East Asian & $44(9.3)$ & $35(4.7)$ & & $73(5.5)$ & $68(6.9)$ & \\
\hline Admixed Hispanic & $32(6.8)$ & $23(3.1)$ & & $52(3.9)$ & $31(3.1)$ & \\
\hline $\begin{array}{l}\text { Admixed Non- } \\
\text { Hispanics }\end{array}$ & $71(15)$ & $39(5.3)$ & & $132(9.9)$ & $77(7.8)$ & \\
\hline
\end{tabular}

Age was defined at first ever event for cases, study visit date for controls. The age cutoff for a "young case" was not the same for males (<45 years) and females ( $<55$ years). $\nmid P<0.00 I$ for Wilcoxon test.

risk factors (smoking, hypertension, high cholesterol, and diabetes) were defined based on self report and were considered to be present only if subjects reported an age of onset of a risk factor that was younger than the age of onset of clinically significant CAD.

\section{Sequencing \& Genotyping}

Using an automated fluorescent labeling system [33], we resequenced the promoter region, the exons including the $5 '$ and 3 ' untranslated regions (UTRs), and the intronexon boundaries of OLR1 in 24 ethnically diverse males with a history of CAD (SNP discovery set). A subset of all SNPs identified by sequencing was then genotyped in all participants of the ADVANCE study using the TaqMan ${ }^{\circledR}$ assay. In addition, a random sample of approximately $15 \%$ of all genotyped SNPs was genotyped in duplicate. The discrepancy rate among all SNPs that were either sequenced and genotyped or genotyped in duplicate was $0.002 \%$. We were unable to make a genotype call in only
$0.35 \%$ of the samples. For LOX1.2 and LOX1.3 the reference strand used for the determination of the minor allele was chosen to be consistent with dbSNP convention. Information on all SNPs from the SNP discovery effort has been submitted to the national dbSNP database.

The subset of sequenced SNPs for genotyping in all study participants using the TaqMan ${ }^{\circledR}$ assay [33] was selected on the basis of the minor allele frequency observed in the SNP discovery set, the predicted functional effect, and the degree of linkage disequilibrium between SNPs. In general, we prioritized for genotyping SNPs with a higher MAF (to maximize statistical power), SNPs in exonic or promoter regions (to maximize the probability of a functional effect). When possible, we genotyped SNPs not in strong linkage disequilibrium (LD) with each other to try to identify as many haplotypes as possible across our regions of interest. All resequencing and genotyping was performed by the Stanford Human Genome Center. 


\section{Statistical Analysis}

We excluded from further analysis subjects who did not provide blood for DNA extraction $(n=40)$ and who did not fill out the study questionnaire $(n=9)$. We also excluded South Asians ( $\mathrm{n}=55)$ because of a lack of controls. Lastly, we excluded Pacific Islanders $(n=9)$ and Native Americans $(n=2)$ because of small numbers.

For each set of cases and controls, we compared the distributions and frequencies of all non-genetic covariates of interest using standard parametric and non-parametric methods. For each race/ethnic group, we calculated minor allele frequencies of all SNPs genotyped in all participants and tested for Hardy-Weinberg equilibrium (HWE) with the permutation version of the exact test [34]. Using multivariate unconditional logistic regression, we then calculated odds ratios (ORs) for symptomatic CAD associated with the minor allele for each of the three traditional modes of inheritance (recessive, additive, dominant). All ORs were first adjusted for age, gender, self-reported race/ ethic group, and source of cases and controls (young set vs old set) and then further adjusted for BMI, smoking status (ever versus never), hypertension, diabetes, and hyperlipidemia. To minimize the probability of confounding due to population substructure in our 'Admixed Hispanic' and 'Admixed Non-Hispanic' race/ethnic groups, we estimated the proportion of white/European, black/AfricanAmerica, Hispanic and East Asian ancestry at the individual level for all cases and controls in these groups and used these estimates as covariates in our fully adjusted analyses[35]. For each SNP, we also tested for the presence of heterogeneity among the ORs across all race/ethnic groups and both set of cases and controls using appropriate interaction terms in the co-dominant logistic model.

For LOX1.2 and LOX1.3, we calculated the power of our study sample to detect the odds ratios we observed for that SNP. For these calculations, we assumed the polymorphism was causal, a population prevalence of symptomatic CAD of $6.2 \%$ [36] and a Type 1 error of 0.05 .

We used SAS v 9.1.3 including the SAS genetics module v. 2.2, STRUCTURE[35], and the genetic power calculator [37], to carry out all analyses.

\section{Replication in the ARIC Study}

To avoid reporting spurious findings, it is necessary to replicate putative associations in an independent cohort [22]. Study participants were selected from the ARIC Study, a prospective investigation of atherosclerosis and its clinical sequelae involving 15,792 individuals from four communities aged 45-64 years at recruitment (1987-1989). A detailed description of the ARIC Study design and methods have been published previously [38-43]. Incident coronary heart disease (CHD) cases were defined as definite or probable MI, a silent MI between examinations by ECG, a definite CAD death or coronary revascularization. Genotyping the LOX1.2 SNP (Lys167Asn) was performed using the TaqMan Assay (Applied Biosystems, Foster City, CA) (primers available on request). The LOX1.3 SNP was assayed using a pre-made, validated assay from ABI (assay ID C-3130875-).

Follow-up was available until December 31, 2002. Timeto-event was analyzed using Cox proportional hazards modeling. We adopted the methods of Hsieh and Lavori [44] to calculate post-hoc the minimal detectable hazard ratio based on the standard deviation of genotypes where homozygote major equals 0 , heterozygote equals 1 and homozygote minor equals 2 .

We used STATA, and PASS [45] to carry out all analyses in the ARIC study.

\section{Consent and Institutional Review Board Approval}

The ADVANCE study was approved by the Institutional Review Boards (IRBs) at Stanford, the Kaiser Foundation Research Institute and the Palo Alto Veterans Administration Hospital. The ARIC study was approved by all participating institutional IRBs. All subjects in both the ADVANCE and ARIC studies gave written informed consent.

\section{Results}

\section{Non-genetic covariates of interest in ADVANCE}

The study population consisted of 3,543 subjects $(1,809$ cases and 1,734 controls). The prevalence of most traditional risk factors of atherosclerosis was significantly greater in cases than in controls (Table 1). The lower prevalence of males in the younger case/control set and the younger age of cases in the older case/control set were the result of stratified sampling. Stratified sampling and/or preferential participation also led to differences in the prevalence of certain race/ethnic groups.

\section{LOXI SNP discovery}

We identified 16 SNPs by sequencing the promoter region, the exons and flanking intronic regions of OLR 1 in the 24 subjects of different ethnic groups from our SNP discovery set (Figure 1). In the promoter region, our SNP discovery primer set started approximately 620 bp 5' from the transcription start site. Three of these SNPs had minor allele frequencies (MAFs) of $2 \%$ and were not analyzed further. The remaining SNPs had MAFs of $20 \%$ or greater over all race/ethnic groups, and of these SNPs LOX 1.1 (rs2742112), LOX 1.2 (rs11053646), LOX 1.3 (rs3736232) and LOX 1.16 (rs1050286) were selected for genotyping in all participants in the ADVANCE study. Minor allele frequencies for these SNPs are shown in Table 2. 
Table 2: SNPs in the LOX-I gene that were genotyped in ADVANCE subjects

\begin{tabular}{|c|c|c|c|c|c|c|c|c|}
\hline \multirow[t]{2}{*}{ SNP Name } & \multirow[t]{2}{*}{ dbSNP } & \multirow[t]{2}{*}{ Type } & \multirow[t]{2}{*}{ Change } & \multirow{2}{*}{$\begin{array}{c}\text { Minor/Major } \\
\text { Allele }\end{array}$} & \multicolumn{4}{|c|}{ Minor Allele Freq (\%) } \\
\hline & & & & & $\begin{array}{l}\text { Whitel } \\
\text { European }\end{array}$ & $\begin{array}{c}\text { Black/African } \\
\text { American }\end{array}$ & East Asian & Hispanic \\
\hline LOXI.I & rs 2742112 & $5^{\prime}$ & $3915^{\prime}$ transc start & $\mathrm{A} / \mathrm{G}$ & 31 & 46 & 57 & 39 \\
\hline LOXI.2 & rsII 053646 & exon & $\begin{array}{l}\text { mRNA 563, } \\
\text { Lys-Asn }\end{array}$ & $\mathbf{C} / \mathbf{G}$ & 9 & 20 & 16 & 6 \\
\hline LOXI.3 & rs3736232 & intron & $263^{\prime}$ exon 4 & $\mathrm{C} / \mathrm{G}$ & 49 & 20 & 23 & 49 \\
\hline LOXI.16 & rsl050286 & exon & 3' UTR & $\mathrm{G} / \mathrm{A}$ & 49 & 23 & 23 & 50 \\
\hline
\end{tabular}

Bold indicates non-synonymous amino acid change. For association analysis, the minor allele is defined as the least prevalent allele across both sets of controls in all race/ethnic groups combined.

\section{Association analysis in ADVANCE}

We found no evidence of heterogeneity of the ORs across race/ethnic groups and the two sets of cases and controls ( "younger" versus "older") for the additive logistic model (details not shown). Therefore, in Tables 3 and 4 , we only present the OR for each inheritance model across both sets of cases and controls only stratified by race/ethnic group and combined across race/ethnic groups.

The LOX 1.1 SNP in the promoter region of the gene was not associated with clinical CAD. However, the "C" allele of the LOX 1.2 SNP (G501C leading to Lys167Asn) was associated with a decreased risk of CAD (MAF of $8.8 \%$ in 1808 cases and $11.9 \%$ in 1731 controls, fully adjusted OR $0.8, \mathrm{P}=0.01)$. This association was also significant in a dominant model but not in a recessive model (Table 3 ). There was no major difference in the OR between the younger set and older set of cases and controls (additive model fully adjusted ORs 0.74 , CI $0.55-1.01, \mathrm{p}=0.06$ and 0.82 , CI $0.67-1.02, \mathrm{P}=0.07$ for younger and older case/ control set respectively). The " $\mathrm{C}$ " allele of the LOX 1.3 SNP was weakly associated with an increased risk of CAD in the combined analysis (MAF of $44.7 \%$ in cases and $39.8 \%$ in controls, fully adjusted model OR $1.13, \mathrm{P}=$ 0.03 ) (Table 4). An association with CAD was also present for the recessive model of this SNP (fully adjusted OR $1.32, \mathrm{P}=0.004)$ but not for a dominant model. There was no major difference in the OR between the younger set and older set of cases and controls (additive model fully adjusted ORs $1.08, \mathrm{CI} 0.88-1.32, \mathrm{p}=0.46$ and $1.15, \mathrm{CI}$ $1.01-1.32, \mathrm{P}=0.03$ for younger and older case/control set respectively). As LOX 1.3 and LOX 1.16 SNPs were found to be in near perfect linkage disequilibrium (details not shown), the results of the association analyses for the LOX 1.16 were essentially identical to LOX1.3 (details not shown).

We performed additional analyses using only the subset of young and old cases presenting with AMI [see Addi- tional file 1]. The results for both SNPs (LOX1.2 and LOX1.3) are not substantially different in any of the three models (recessive, additive or dominant either minimally or fully adjusted) whether cases include all subjects with clinically significant $C A D$ versus cases presenting with MI. While the point estimates for the odds ratios are quite similar there is a loss of significance in the MI comparison presumably because of a decrease in power caused by excluding subjects with incident angina. For instance, LOX 1.2 in our overall analysis has a fully adjusted, additive model OR $0.8(0.68-0.95, \mathrm{P}<0.05)$ for the "clinically significant CAD vs control" as compared to an OR 0.84 $(0.69-1.02, \mathrm{P}=0.07)$ for the "MI vs control" comparison. Similar results were found for LOX 1.3 (OR 1.13, 1.0$1.25, \mathrm{P}<0.05$ vs $1.08,0.96-1.22, \mathrm{P}=0.19$ ).

For the least common LOX-1 SNP across all race/ethnic groups combined (LOX1.2), the minimal detectable ORs was 1.2 for an additive model assuming that the minor allele increases risk and 0.71 assuming the minor allele decreases risk.

\section{Replication in ARIC}

Non-genetic characteristics of the ARIC sample are summarized in Table 5. Genotype counts in the ARIC cohort for LOX 1.2 and LOX 1.3 are summarized in Table 6 . LOX1.2 was genotyped in a total of 9,858 white and 3,367 African American individuals and the LOX 1.3 SNP was genotyped in 9,844 white and 3,359 African American individuals. After stratification by race, all race/ethnic specific genotype counts were in HWE with the exception of LOX 1.3 which showed some evidence of deviation from HWE in African American subjects $(\mathrm{P}<0.01)$. The MAFs for these SNPs were very similar to that seen in the ADVANCE cohort.

Table 6 also summarizes hazard rate ratios (HRR) for symptomatic CHD for the minor allele of each SNP. For LOX1.2, neither the minimally adjusted nor the fully 
Table 3: Genotype counts and ORs for LOX I.2 in the ADVANCE study combining both sets of cases and controls

\begin{tabular}{|c|c|c|c|c|c|c|c|c|c|}
\hline \multirow[b]{3}{*}{ LOXI.2 } & \multirow{3}{*}{ Genotype } & \multirow{3}{*}{$\begin{array}{c}\text { Cases N } \\
(\%)\end{array}$} & \multirow{3}{*}{$\begin{array}{c}\text { Controls N } \\
(\%))\end{array}$} & \multicolumn{2}{|c|}{ Recessive } & \multicolumn{2}{|c|}{ Additive } & \multicolumn{2}{|c|}{ Dominant } \\
\hline & & & & $\begin{array}{c}\text { minimal } \\
\text { model }\end{array}$ & $\begin{array}{c}\text { fully } \\
\text { adjusted } \\
\text { model }\end{array}$ & $\begin{array}{l}\text { minimal } \\
\text { model }\end{array}$ & $\begin{array}{c}\text { fully } \\
\text { adjusted } \\
\text { model }\end{array}$ & $\begin{array}{l}\text { minimal } \\
\text { model }\end{array}$ & $\begin{array}{c}\text { fully } \\
\text { adjusted } \\
\text { model }\end{array}$ \\
\hline & & & & $\begin{array}{l}\text { OR } \\
\text { Cl }\end{array}$ & $\begin{array}{l}\text { OR } \\
\text { Cl }\end{array}$ & $\begin{array}{l}\text { OR } \\
\text { Cl }\end{array}$ & $\begin{array}{l}\text { OR } \\
\text { Cl }\end{array}$ & $\begin{array}{l}\text { OR } \\
\text { Cl }\end{array}$ & $\begin{array}{l}\text { OR } \\
\text { Cl }\end{array}$ \\
\hline \multirow[t]{3}{*}{ White } & GG & $1034(86)$ & $842(80)$ & & & & & & \\
\hline & GC & $154(13)$ & $194(19)$ & $\begin{array}{c}1.44 \\
0.6-3.6\end{array}$ & $\begin{array}{l}1.59 \\
0.6-4.0\end{array}$ & $\begin{array}{l}\mathbf{0 . 7 5} * * \\
0.6-0.9\end{array}$ & $\begin{array}{c}\mathbf{0 . 7 6} * \\
0.6-0.95\end{array}$ & $\begin{array}{l}0.69 * * \\
0.6-0.9\end{array}$ & $\begin{array}{c}\mathbf{0 . 7} \text { ** } \\
0.6-0.9\end{array}$ \\
\hline & $\mathrm{CC}$ & $12(I)$ & $9(1)$ & & & & & & \\
\hline \multirow[t]{3}{*}{ Black/AA } & GG & $65(68)$ & $201(6 I)$ & & & & & & \\
\hline & GC & $30(31)$ & 118 (36) & $\begin{array}{c}0.25 \\
0.01-1.4\end{array}$ & $\begin{array}{c}0.23 \\
0.01-1.3\end{array}$ & $\begin{array}{c}0.8 \\
0.5-1.3\end{array}$ & $\begin{array}{c}0.77 \\
0.47-1.2\end{array}$ & $\begin{array}{c}0.85 \\
0.5-1.4\end{array}$ & $\begin{array}{c}0.82 \\
0.5-1.4\end{array}$ \\
\hline & $\mathrm{CC}$ & I (I) & $12(3)$ & & & & & & \\
\hline \multirow[t]{3}{*}{ Hispanic } & GG & $96(89)$ & $73(89)$ & & & & & & \\
\hline & GC & $12(11)$ & $9(11)$ & $\begin{array}{c}\text { I } \\
\text { NA }\end{array}$ & $\begin{array}{c}\text { I } \\
\text { NA }\end{array}$ & $\begin{array}{c}1.05 \\
0.4-2.9\end{array}$ & $\begin{array}{c}1.18 \\
0.4-3.4\end{array}$ & $\begin{array}{c}1.05 \\
0.4-2.9\end{array}$ & $\begin{array}{c}1.18 \\
0.4-3.4\end{array}$ \\
\hline & $\mathrm{CC}$ & $0(0)$ & $0(0)$ & & & & & & \\
\hline \multirow[t]{3}{*}{ E. Asian } & GG & 90 (77) & $66(64)$ & & & & & & \\
\hline & GC & $23(20)$ & $33(32)$ & $\begin{array}{c}1.02 \\
0.2-4.9\end{array}$ & $\begin{array}{c}1.94 \\
0.2-4.8\end{array}$ & $\begin{array}{c}0.61 \\
0.4-1.0\end{array}$ & $\begin{array}{c}\mathbf{0 . 5 6} * \\
0.3-0.98\end{array}$ & $\begin{array}{c}\mathbf{0 . 4 9} * \\
0.3-0.9\end{array}$ & $\begin{array}{c}\mathbf{0 . 4 5} * \\
0.2-0.97\end{array}$ \\
\hline & $\mathrm{CC}$ & $4(3)$ & $4(4)$ & & & & & & \\
\hline \multirow[t]{3}{*}{ Mix. Hisp. } & GG & $72(86)$ & $48(89)$ & & & & & & \\
\hline & GC & $11(13)$ & $6(11)$ & $\begin{array}{c}3 \mathrm{E}+09 \\
\mathrm{NA}\end{array}$ & $\begin{array}{c}8 \mathrm{E}+08 \\
\mathrm{NA}\end{array}$ & $\begin{array}{c}1.66 \\
0.6-5.5\end{array}$ & $\begin{array}{c}1.5 \mid \\
0.5-5.3\end{array}$ & $\begin{array}{c}1.64 \\
0.5-5.6\end{array}$ & $\begin{array}{c}I .5 \mid \\
0.46-5.3\end{array}$ \\
\hline & $\mathrm{CC}$ & I (I) & $0(0)$ & & & & & & \\
\hline \multirow[t]{3}{*}{ Mix. other } & GG & $150(74)$ & $92(79)$ & & & & & & \\
\hline & GC & $53(26)$ & $21(18)$ & $\begin{array}{l}0^{*} \\
\text { NA }\end{array}$ & $\begin{array}{l}\mathbf{0}^{*} \\
\text { NA }\end{array}$ & $\begin{array}{c}1.32 \\
0.8-2.3\end{array}$ & $\begin{array}{c}1.28 \\
0.73-2.3\end{array}$ & $\begin{array}{c}1.6 \\
0.9-3.0\end{array}$ & $\begin{array}{c}1.56 \\
0.8-3.0\end{array}$ \\
\hline & $\mathrm{CC}$ & $0(0)$ & $3(3)$ & & & & & & \\
\hline \multirow[t]{3}{*}{ All } & GG & I507 (83) & $1322(76)$ & & & & & & \\
\hline & GC & $283(16)$ & 381 (22) & $\begin{array}{c}0.8 \\
0.4|-| .5\end{array}$ & $\begin{array}{c}0.8 \\
0.4|-| .5\end{array}$ & $\begin{array}{c}\mathbf{0 . 8 * *} \\
0.7-0.9\end{array}$ & $\begin{array}{c}\mathbf{0 . 8 *} \\
0.7-0.95\end{array}$ & $\begin{array}{c}\mathbf{0 . 7 7} * * \\
0.6-0.93\end{array}$ & $\begin{array}{c}\mathbf{0 . 7 8} * * \\
0.7-0.94\end{array}$ \\
\hline & $\mathrm{CC}$ & $18(1)$ & $28(2)$ & & & & & & \\
\hline
\end{tabular}

$\mathrm{OR}=$ Odds ratio, ref $=$ reference group, $\mathrm{NA}=$ unable to compute, All $\mathrm{P}$ values $<0.05$ in bold, $* \mathrm{P}<0.05$, $* * \mathrm{P}<0.0 \mathrm{I}$.

t combined analyses adjusted for race/ethnic group and case/control set

Minimal model adjusted for age, sex. Fully adjusted analyses adjusted for age, sex, BMI, smoking status, hypertension, diabetes, high cholesterol,

"admixed" strata further adjusted for proportion of white, black, Hispanic, E. Asian ancestry derived from STRUCTURE analyses. Non-stratified

analyses further adjusted by race/ethnic group and cases/control status.

adjusted models demonstrated an association with incident CHD. For LOX1.3, the minor allele showed a nominally significant association with clinical CHD but in the opposite direction than that seen in the ADVANCE study (HRR 0.92, P = 0.04 for the additive model).

We also performed analyses in ARIC in subjects presenting with "incident MI + fatal CHD" as well as "incident non-fatal MI" (see Additional file 1). The results do not differ substantially from those using "incident CHD". For these three comparisons (incident CHD, incident $\mathrm{MI}+$ fatal CHD, incident non-fatal MI) the overall HRR, CI and $P$ values in fully adjusted additive model for LOX 1.2 are: $0.99,0.9-1.1$, NS; $0.98,0.9-1.1$, NS; $0.98,0.8-1.2$, NS and for LOX 1.3 are: $0.92,0.9-1.0, \mathrm{P}=0.04 ; 0.88,0.8-1.0$, $\mathrm{P}=0.01 ; 0.91,0.8-1$, NS.
The minimal detectable HRR in the ARIC study for LOX1.2 SNP was estimated to be 1.17 for an additive model assuming the minor allele increases risk and 0.85 assuming the minor allele decreases risk.

\section{Discussion}

Oxidized LDL plays a key role in the initiation of atherosclerotic lesions. As an endothelial receptor for oxLDL, LOX-1 has been shown to initiate pro-atherogenic cascades and is an attractive candidate gene for CAD susceptibility $[2,4-10,46]$. We sought to determine whether SNPs in the LOX-1 gene, OLR1 are associated with CAD. In our discovery sample (ADVANCE), we found nominally significant associations of a non-synonymous coding SNP (LOX 1.2) and an intronic SNP (LOX 1.3) with clinical CAD. However, we were unable to replicate these findings in an independent sample (the ARIC study) with ade- 
Table 4: Genotype counts and ORs for LOX I.3 in the ADVANCE study combining both sets of cases and controls

\begin{tabular}{|c|c|c|c|c|c|c|c|c|c|}
\hline \multirow[b]{3}{*}{ LOXI.3 } & \multirow{3}{*}{ Genotype } & \multirow{3}{*}{$\begin{array}{c}\text { Cases N } \\
(\%)\end{array}$} & \multirow{3}{*}{$\begin{array}{c}\text { Controls N } \\
(\%))\end{array}$} & \multicolumn{2}{|c|}{ Recessive } & \multicolumn{2}{|c|}{ Additive } & \multicolumn{2}{|c|}{ Dominant } \\
\hline & & & & $\begin{array}{c}\text { minimal } \\
\text { model }\end{array}$ & $\begin{array}{c}\text { fully } \\
\text { adjusted } \\
\text { model }\end{array}$ & $\begin{array}{c}\text { minimal } \\
\text { model }\end{array}$ & $\begin{array}{c}\text { fully } \\
\text { adjusted } \\
\text { model }\end{array}$ & $\begin{array}{c}\text { minimal } \\
\text { model }\end{array}$ & $\begin{array}{c}\text { fully } \\
\text { adjusted } \\
\text { model }\end{array}$ \\
\hline & & & & $\begin{array}{l}\text { OR } \\
\text { CI }\end{array}$ & $\begin{array}{l}\text { OR } \\
\text { CI }\end{array}$ & $\begin{array}{l}\text { OR } \\
\text { Cl }\end{array}$ & $\begin{array}{l}\text { OR } \\
\text { Cl }\end{array}$ & $\begin{array}{l}\text { OR } \\
\text { Cl }\end{array}$ & $\begin{array}{l}\text { OR } \\
\text { CI }\end{array}$ \\
\hline \multirow[t]{3}{*}{ White } & GG & $290(24)$ & $269(26)$ & & & & & & \\
\hline & GC & $603(5 \mathrm{I})$ & $560(54)$ & $\begin{array}{l}1.29 * \\
1.1-1.6\end{array}$ & $\begin{array}{c}1.3^{*} \\
1.1-1.6\end{array}$ & $\begin{array}{c}1.13 \\
1.0-1.3\end{array}$ & $\begin{array}{c}1.13 \\
1.0-1.3\end{array}$ & $\begin{array}{c}1.08 \\
0.88-1.3\end{array}$ & $\begin{array}{c}1.08 \\
0.88-1.3\end{array}$ \\
\hline & $\mathrm{CC}$ & $301(25)$ & $216(20)$ & & & & & & \\
\hline \multirow[t]{3}{*}{ Black/AA } & GG & $55(58)$ & $223(67)$ & & & & & & \\
\hline & GC & $30(3 I)$ & $90(27)$ & $\begin{array}{c}2.31 \\
0.92-5.6\end{array}$ & $\begin{array}{c}2.5 \\
0.95-6.3\end{array}$ & $\begin{array}{c}1.47 \\
0.99-2.2\end{array}$ & $\begin{array}{c}1.49 \\
0.99-2.2\end{array}$ & $\begin{array}{c}1.49 \\
0.89-2.5\end{array}$ & $\begin{array}{c}1.49 \\
0.88-2.5\end{array}$ \\
\hline & $\mathrm{CC}$ & $10(11)$ & $18(6)$ & & & & & & \\
\hline \multirow[t]{3}{*}{ Hispanic } & GG & $43(30)$ & $20(24)$ & & & & & & \\
\hline & GC & $45(45)$ & $4 I(50)$ & $\begin{array}{c}1.02 \\
0.5-2.1\end{array}$ & $\begin{array}{c}0.76 \\
0.34-1.7\end{array}$ & $\begin{array}{c}0.92 \\
0.6-1.4\end{array}$ & $\begin{array}{c}0.85 \\
0.53-1.4\end{array}$ & $\begin{array}{c}0.78 \\
0.38-1.6\end{array}$ & $\begin{array}{c}0.85 \\
0.39-1.8\end{array}$ \\
\hline & $\mathrm{CC}$ & $19(25)$ & $21(26)$ & & & & & & \\
\hline \multirow[t]{3}{*}{ E. Asian } & GG & $65(56)$ & $64(62)$ & & & & & & \\
\hline & GC & $44(38)$ & $35(34)$ & $\begin{array}{c}2.26 \\
0.6-10\end{array}$ & $\begin{array}{c}2.56 \\
0.64-12\end{array}$ & $\begin{array}{c}1.26 \\
0.78-2.0\end{array}$ & $\begin{array}{c}1.25 \\
0.76-2.1\end{array}$ & $\begin{array}{c}1.2 \\
0.67-2.2\end{array}$ & $\begin{array}{c}1.16 \\
0.04-2.1\end{array}$ \\
\hline & $\mathrm{CC}$ & $7(6)$ & $4(4)$ & & & & & & \\
\hline \multirow[t]{3}{*}{ Mix. Hisp. } & GG & $21(25)$ & $I I(2 I)$ & & & & & & \\
\hline & GC & $39(46)$ & 31 (58) & $\begin{array}{c}1.39 \\
0.6-3.7\end{array}$ & $\begin{array}{c}1.45 \\
0.59-3.7\end{array}$ & $\begin{array}{c}1.02 \\
0.59-1.7\end{array}$ & $\begin{array}{c}1.04 \\
0.6-1.8\end{array}$ & $\begin{array}{c}0.73 \\
0.29-1.8\end{array}$ & $\begin{array}{c}0.76 \\
0.3-1.9\end{array}$ \\
\hline & $\mathrm{CC}$ & $24(29)$ & II (2I) & & & & & & \\
\hline \multirow[t]{3}{*}{ Mix. other } & GG & $87(43)$ & $49(44)$ & & & & & & \\
\hline & GC & 79 (39) & $48(43)$ & $\begin{array}{c}1.01 \\
0.5-2.1\end{array}$ & $\begin{array}{c}0.98 \\
0.47-2.1\end{array}$ & $\begin{array}{c}0.42 \\
0.64-1.4\end{array}$ & $\begin{array}{c}0.93 \\
0.63-1.4\end{array}$ & $\begin{array}{c}0.85 \\
0.49-1.5\end{array}$ & $\begin{array}{c}0.86 \\
0.5-1.5\end{array}$ \\
\hline & $\mathrm{CC}$ & $35(18)$ & $14(13)$ & & & & & & \\
\hline \multirow[t]{3}{*}{ All } & GG & $570(32)$ & $636(37)$ & & & & & & \\
\hline & GC & 847 (47) & 805 (47) & $\begin{array}{l}1.3^{*} \\
1.1-1.6\end{array}$ & $\begin{array}{l}1.32^{* *} \\
1.1-1.6\end{array}$ & $\begin{array}{l}1.12^{*} \\
1.0-1.2\end{array}$ & $\begin{array}{l}1.13^{*} \\
1.0-1.25\end{array}$ & $\begin{array}{c}1.06 \\
0.9-1.25\end{array}$ & $\begin{array}{c}1.07 \\
0.9-1.25\end{array}$ \\
\hline & $\mathrm{CC}$ & $380(2 \mathrm{I})$ & $284(16)$ & & & & & & \\
\hline
\end{tabular}

$\mathrm{OR}=$ Odds ratio, ref $=$ reference group, $\mathrm{NA}=$ unable to compute, $\mathrm{All} \mathrm{P}$ values $<0.05$ in bold, $* \mathrm{P}<0.05, * * \mathrm{P}<0.0 \mathrm{I}$

t combined analyses adjusted for race/ethnic group and case/control set

Minimal model adjusted for age, sex. Fully adjusted analyses adjusted for age, sex, BMI, smoking status, hypertension, diabetes, high cholesterol,

"admixed" strata further adjusted for proportion of white, black, Hispanic, E. Asian ancestry derived from STRUCTURE analyses. Non-stratified

analyses further adjusted by race/ethnic group and cases/control status

quate power to detect the risk ratio observed in the discovery sample.

Previous human genetic association studies of the LOX1.2 variant (G501C) have yielded conflicting results [13$15,21]$. Recently, Morgan et al. were not able to show an association of this SNP with acute coronary syndrome in a study of over 1,400 white subjects [16]. Although the predicted amino acid change (Lys167Asn) occurs in the $\alpha 1$ helix in a region called the "acid-base patch" that might be important for secondary binding of oxLDL $[4,5]$, to our knowledge, there are no reports detailing the effect of the Lys167Asn on oxLDL binding.

Mango et al. studied both the G501C SNP as well as a group of SNPs in introns (rs3736232, rs3736234, rs3736235, rs17174597, rs13306593) and the 3'UTR (rs 1050283) of OLR1 that were in very strong LD with one another. They found that these non-coding SNPs were highly associated with MI, the OR for MI for carriers of the minor allele at the 3'UTR was 3.7 [14]. This group has recently shown that this group of non-coding SNPs regulates the production of a splice variant of LOX-1 (termed LOXIN), which results in a less robust response to oxLDL and decreased apoptotic signaling. Carriers of the minor alleles of these non-coding SNPs produce less LOXIN, and thus may be at increased risk of CAD [47]. We did genotype one of the SNPs identified by Mango et al. (LOX 1.3, rs3736232) and also found that presence of the minor "C" allele was associated with CAD. However, our efforts to replicate this finding in ARIC were not successful.

In CAD alone, many initially positive reports have not withstood the test of replication in other cohorts The rea- 
Table 5: Characteristics of Incident Coronary Heart Disease cases and non-cases in the Atherosclerosis Risk in Communities cohort, stratitifed by race

\begin{tabular}{|c|c|c|c|c|c|c|}
\hline & \multicolumn{3}{|c|}{ Whites } & \multicolumn{3}{|c|}{ African Americans } \\
\hline & $\begin{array}{c}\text { Cases } \\
(n=1,168)\end{array}$ & $\begin{array}{l}\text { Non-Cases } \\
(\mathrm{n}=8,802)\end{array}$ & & $\begin{array}{c}\text { Cases } \\
(n=319)\end{array}$ & $\begin{array}{l}\text { Non-Cases } \\
(\mathrm{n}=3,119)\end{array}$ & \\
\hline & Mean (SEM) & Mean (SEM) & $\mathrm{P} * *$ & Mean (SEM) & Mean (SEM) & $\mathrm{P} * *$ \\
\hline Age (years) ${ }^{\dagger}$ & $55.7(0.2)$ & $53.9(0.06)$ & $<0.0001$ & $55(0.3)$ & $53.1(0.1)$ & $<0.0001$ \\
\hline Age at event (years) & $63.9(0.2)$ & -- & & $63.0(0.4)$ & -- & \\
\hline Body Mass Index $(\mathrm{kg} / \mathrm{m} 2)^{\dagger}$ & $27.8(0.1)$ & $26.8(0.05)$ & $<0.0001$ & $30(0.3)$ & $29.5(0.1)$ & 0.1 \\
\hline HDL Cholesterol $(\mathrm{mg} / \mathrm{dL})^{\dagger}$ & $42.8(0.4)$ & $52.2(0.2)$ & $<0.0001$ & $48.6(0.8)$ & $56.0(0.3)$ & $<0.0001$ \\
\hline \multirow[t]{2}{*}{ Total Cholesterol $(\mathrm{mmol} / \mathrm{L})^{\dagger}$} & $5.82(0.03)$ & $5.5(0.01)$ & $<0.0001$ & $5.84(0.07)$ & $5.5 \mathrm{I}(0.02)$ & $<0.0001$ \\
\hline & $\%$ & $\%$ & $\mathrm{P} * *$ & $\%$ & $\%$ & $\mathrm{P} * *$ \\
\hline Males & 69.4 & 42.2 & $<0.001$ & 49.5 & 35.9 & $<0.001$ \\
\hline Diabetes ${ }^{\dagger}$ & 20.2 & 6.6 & $<0.001$ & 34.2 & 16.4 & $<0.001$ \\
\hline Hypertension ${ }^{\dagger}$ & 38.6 & 23.7 & $<0.001$ & 72.7 & 52.1 & $<0.001$ \\
\hline Smoking ${ }^{\dagger}$ & 31.4 & 23.6 & $<0.001$ & 42 & 27.9 & $<0.001$ \\
\hline
\end{tabular}

SEM = Standard error of the mean

*P-value comparing means or proportions between cases and non-cases

†At the baseline visit

sons for the frequent failure of candidate gene studies to date to detect robust associations have been widely reviewed [16,48-53].

As in all population genetic studies, the probability of reporting a false negative finding exists. This probability increases significantly in underpowered studies. A key strength of this report is the large number of cases and controls enrolled in the ADVANCE study and the large number of participants in the ARIC study. Thus, based on our power estimates for each study, it is unlikely that we missed a large effect.

Our study has several limitations. First, the ADVANCE study did not enroll cases that either died or were too ill to participate at any time after their incident event and prior to the clinic visit. It is difficult to predict what effect, if any, this selection bias may have had on our observed ORs. Regardless, this selection bias was not present in the ARIC cohort study, which captured incident fatal events. Second, the ARIC study did not have many cases with an age of onset in the same age range as the young cases in the ADVANCE study. Because genotypic effects on CAD risk are generally expected to be greater in subjects with early onset disease [54], a reasonable argument could be made that our inability to replicate associations in the ARIC study was a consequence of a paucity of early onset cases in that cohort. However, the ARIC study still had adequate power to detect the OR noted in the ADVANCE late onset cases and controls for both LOX1.2 and LOX1.3. Furthermore, the nominally significant HRR for LOX1.3 in the opposite direction of the ADVANCE study serves as further compelling evidence that the initial finding was a false positive. Third, because we did not genotype all possible variants or tag SNPs we cannot be certain that other common allelic variants of this gene are not associated with CAD. Based on HapMap data, at least 8 tagged SNPs in white/Europeans and 14 tagSNPs in African Americans ( $\mathrm{r}^{2}$ between all SNPs in a bin of $\geq 0.8$, minimum minor allele frequency of $1 \%$ ) would have to be genotyped in this gene to efficiently capture all common haplotypes [55]. However, we did genotype the only validated coding SNP in OLR1.

\section{Conclusion}

Large well-powered allelic association studies have great potential for identification of CAD susceptibility genes. The LOX 1.2 and LOX 1.3 SNPs are particularly attractive because the mechanism for risk modification is plausible. We found tentative associations for these SNPs in the ADVACE study. However, all studies like ADVANCE have statistical limitations due to multiple comparisons. To prevent spurious associations, the accepted standard for such analyses is independent replication in another cohort $[48-50,56]$. We attempted to replicate our findings in the ARIC study, a large community based study of the genetics of atherosclerosis in whites and African Americans. Putative associations must be replicated in multiple large cohorts before they can be assumed to be real. Thus, the overall set of analyses does not support an association between these SNPs and CAD. 
Table 6: Allele frequencies and Hazard Rate Ratios for incident CAD for minor alleles of LOX I.2, LOX I.3 in the Atherosclerosis Risk In Communities study

\begin{tabular}{|c|c|c|c|c|c|c|c|c|c|}
\hline & \multirow[b]{2}{*}{ geno } & \multirow[b]{2}{*}{$\begin{array}{c}\text { Cases } \\
\text { counts (\%) }\end{array}$} & \multirow[b]{2}{*}{$\begin{array}{l}\text { Non-cases } \\
\text { counts (\%) }\end{array}$} & \multicolumn{2}{|c|}{ Recessive } & \multicolumn{2}{|c|}{ Additive } & \multicolumn{2}{|c|}{ Dominant } \\
\hline & & & & $\begin{array}{c}\text { model I } \\
\text { HR } \\
\mathrm{Cl}\end{array}$ & $\begin{array}{c}\text { model } 2 \\
\text { HR } \\
\text { Cl }\end{array}$ & $\begin{array}{c}\text { model I } \\
\text { HR } \\
\text { Cl }\end{array}$ & $\begin{array}{c}\text { model } 2 \\
\text { HR } \\
\mathrm{Cl}\end{array}$ & $\begin{array}{c}\text { model I } \\
\text { HR } \\
\text { Cl }\end{array}$ & $\begin{array}{c}\text { model } 2 \\
\text { HR } \\
\text { Cl }\end{array}$ \\
\hline \multicolumn{10}{|l|}{ LOX 1.2} \\
\hline \multirow[t]{4}{*}{ Whites } & GG & $938(8 \mathrm{I})$ & $7075(81)$ & & & & & & \\
\hline & CG & 204 (18) & $1549(18)$ & $\begin{array}{c}1.22 \\
0.7-2.1\end{array}$ & $\begin{array}{c}1.23 \\
0.7-2.1\end{array}$ & $\begin{array}{c}1.01 \\
0.88-1.2\end{array}$ & $\begin{array}{c}0.99 \\
0.86-1.1\end{array}$ & $\begin{array}{c}1 \\
0.86-1.2\end{array}$ & $\begin{array}{c}0.97 \\
0.84-1.1\end{array}$ \\
\hline & $\mathrm{CC}$ & $14(1)$ & $78(I)$ & & & & & & \\
\hline & Total & 1156 & 8702 & & & & & & \\
\hline \multirow[t]{4}{*}{ AA } & GG & 185 (59) & $|84|(60)$ & & & & & & \\
\hline & CG & 118 (38) & $1056(35)$ & $\begin{array}{c}0.72 \\
0.4-1.3\end{array}$ & $\begin{array}{c}0.79 \\
0.4-1.4\end{array}$ & $\begin{array}{c}\text { I } \\
0.83-1.2\end{array}$ & $\begin{array}{c}0.98 \\
0.8-1.2\end{array}$ & $\begin{array}{c}1.05 \\
0.84-1.3\end{array}$ & $\begin{array}{c}1.01 \\
0.8-1.3\end{array}$ \\
\hline & $\mathrm{CC}$ & II (3) & $156(5)$ & & & & & & \\
\hline & Total & 314 & 3053 & & & & & & \\
\hline \multirow[t]{4}{*}{ All } & GG & $1123(76)$ & $8916(76)$ & & & & & & \\
\hline & CG & $322(22)$ & 2065 (18) & $\begin{array}{c}0.95 \\
0.64-1.4\end{array}$ & $\begin{array}{c}1.0 \\
0.7-1.5\end{array}$ & $\begin{array}{c}1.01 \\
0.9-1.1\end{array}$ & $\begin{array}{c}0.99 \\
0.88-1.1\end{array}$ & $\begin{array}{c}1.01 \\
0.9-1.1\end{array}$ & $\begin{array}{c}0.99 \\
0.88-1.1\end{array}$ \\
\hline & $\mathrm{CC}$ & $25(2)$ & $234(2)$ & & & & & & \\
\hline & Total & 1470 & 11755 & & & & & & \\
\hline \multicolumn{10}{|l|}{ LOXI.3 } \\
\hline \multirow[t]{4}{*}{ Whites } & GG & $342(30)$ & $2393(27)$ & & & & & & \\
\hline & $\mathrm{GC}$ & 560 (48) & $4329(50)$ & $\begin{array}{c}0.93 \\
0.81-1.1\end{array}$ & $\begin{array}{c}0.93 \\
0.81-1.1\end{array}$ & $\begin{array}{c}0.93 \\
0.86-1.0\end{array}$ & $\begin{array}{c}0.94 \\
0.87-1.0\end{array}$ & $\begin{array}{c}0.9 \\
0.8-1.0\end{array}$ & $\begin{array}{c}0.91 \\
0.8-1.0\end{array}$ \\
\hline & $\mathrm{CC}$ & $250(22)$ & $1970(23)$ & & & & & & \\
\hline & Total & 1152 & 8692 & & & & & & \\
\hline \multirow[t]{4}{*}{ AA } & GG & $236(74)$ & 2099 (69) & & & & & & \\
\hline & GC & $72(23)$ & $818(27)$ & $\begin{array}{c}0.79 \\
0.4-1.5\end{array}$ & $\begin{array}{c}0.93 \\
0.5-1.8\end{array}$ & $\begin{array}{c}0.81 \\
0.65-1.0\end{array}$ & $\begin{array}{c}0.85 \\
0.68-1.1\end{array}$ & $\begin{array}{c}0.78 \\
0.6-1.0\end{array}$ & $\begin{array}{c}0.81 \\
0.63-1.0\end{array}$ \\
\hline & $\mathrm{CC}$ & $10(3)$ & $124(4)$ & & & & & & \\
\hline & Total & 318 & 3041 & & & & & & \\
\hline \multirow[t]{4}{*}{ All } & GG & 578 (39) & $4492(38)$ & & & & & & \\
\hline & GC & $632(43)$ & 5147 (44) & $\begin{array}{c}0.92 \\
0.8-1.1\end{array}$ & $\begin{array}{c}0.93 \\
0.81-1.1\end{array}$ & $\begin{array}{c}\mathbf{0 . 9 2} * \\
0.85-0.99\end{array}$ & $\begin{array}{c}\mathbf{0 . 9 2} * \\
0.86-1.0\end{array}$ & $\begin{array}{c}\mathbf{0 . 8 7}^{*} \\
0.78-0.97\end{array}$ & $\begin{array}{c}\mathbf{0 . 8 9} * \\
0.79-0.99\end{array}$ \\
\hline & $\mathrm{CC}$ & $260(18)$ & $2094(18)$ & & & & & & \\
\hline & Total & 1470 & 11733 & & & & & & \\
\hline
\end{tabular}

Model I: adjusted for age and gender (and race in non-stratified analyses).

Model 2: adjusted for age, gender, center, HDL and total cholesterol, BMl, smoking, diabetes and hypertension status (and race in non-stratified analyses). $* \mathrm{P}<0.05$

\section{Competing interests}

The author(s) declare that they have no competing interests.

\section{Authors' contributions}

JWK and TA were responsible for crucial elements of the study design, data analysis and writing the manuscript. TQ, SPF, MH, AG, CI, RM, NR were responsible for original ADVANCE study including obtaining funding, study design, patient recruitment, genotyping and editing the manuscript. JL and AS were responsible for genotyping efforts and participated in data analysis. SS was the liaison with the CARDIA study and participated in obtaining samples used in the current study. EB, MG and KAV were responsible for the genotyping and data analysis from the
ARIC cohort. All authors read and approved the final manuscript.

\section{Additional material}

\section{Additional file 1}

Supplementary tables of LOX1.2 and LOX1.3. These tables detail analysis from both ADVANCE and ARIC specific to myocardial infarction (MI) as an outcome.

Click here for file

[http://www.biomedcentral.com/content/supplementary/14712350-9-23-S1.doc] 


\section{Acknowledgements}

The ADVANCE investigators wish to thank the many participants and staff who contributed to the ADVANCE study.

The ADVANCE study was supported by a grant from the Donald W. Reynolds Foundation, Las Vegas, NV. The first author is supported by PostDoctoral Research Fellowships from the Stanford University School of Medicine as well as the American Heart Association and the Integrated Therapeutics Group, Inc through investigator initiated research grants.

Role of the Sponsor: The funding agency had no role in the design or conduct of the study; collection, management, analysis or interpretation of the data; or in preparation, review, or approval of the manuscript.

The CARDIA study is supported by contracts NOI-HC-48047, NOI-HC48048, NOI-HC-48049, NOI-HC-48050, and NOI-HC-95095 from the National Heart, Lung, and Blood Institute.

The Atherosclerosis Risk in Communities Study is carried out as a collaborative study supported by the National Heart, Lung, and Blood Institute contracts NOI-HC-550I5, NOI-HC-55016, NOI-HC-550I8, NOI-HC$55019, \mathrm{NOI}-\mathrm{HC}-55020$, NOI-HC-5502I, NOI-HC-55022. The authors thank the staff and participants of the ARIC study for their important contributions.

\section{References}

I. Sawamura T, Kume N, Aoyama T, Moriwaki H, Hoshikawa H, Aiba Y, Tanaka T, Miwa S, Katsura Y, Kita T, Masaki T: An endothelial receptor for oxidized low-density lipoprotein. Nature 1997, 386:73-77.

2. Aoyama T, Sawamura T, Furutani Y, Matsuoka R, Yoshida MC, Fujiwara $H$, Masaki T: Structure and chromosomal assignment of the human lectin-like oxidized low-density-lipoprotein receptor-I (LOX-I) gene. Biochem J I999, 339(Pt I): I77-I84.

3. Chen M, Inoue K, Narumiya S, Masaki T, Sawamura T: Requirements of basic amino acid residues within the lectin-like domain of LOX-I for the binding of oxidized low-density lipoprotein. FEBS Lett 2001, 499:215-219.

4. Ohki I, Ishigaki T, Oyama T, Matsunaga S, Xie Q, Ohnishi-Kameyama M, Murata T, Tsuchiya D, Machida S, Morikawa K, Tate S: Crystal structure of human lectin-like, oxidized low-density lipoprotein receptor I ligand binding domain and its ligand recognition mode to OxLDL. Structure (Camb) 2005, I3:905-917.

5. Park H, Adsit FG, Boyington JC: The I.4 angstrom crystal structure of the human oxidized low density lipoprotein receptor lox-I. J Biol Chem 2005, 280:13593-I3599.

6. Sham PC, Cherny SS, Purcell S, Hewitt JK: Power of linkage versus association analysis of quantitative traits, by use of variancecomponents models, for sibship data. Am J Hum Genet 2000, 66:1616-1630.

7. Hayashida K, Kume N, Minami M, Kita T: Lectin-like oxidized LDL receptor-I (LOX-I) supports adhesion of mononuclear leukocytes and a monocyte-like cell line THP-I cells under static and flow conditions. FEBS Lett 2002, 5 I I : I 33- I 38.

8. Li D, Liu L, Chen H, Sawamura T, Mehta JL: LOX-I, an oxidized LDL endothelial receptor, induces CD40/CD40L signaling in human coronary artery endothelial cells. Arterioscler Thromb Vasc Biol 2003, 23:816-82I.

9. Chen J, Mehta JL, Haider N, Zhang X, Narula J, Li D: Role of caspases in Ox-LDL-induced apoptotic cascade in human coronary artery endothelial cells. Circ Res 2004, 94:370-376.

10. Kume N, Kita T: Apoptosis of vascular cells by oxidized LDL: involvement of caspases and LOX-I and its implication in atherosclerotic plaque rupture. Circ Res 2004, 94:269-270.

I I. Kataoka H, Kume N, Miyamoto S, Minami M, Moriwaki H, Murase T, Sawamura T, Masaki T, Hashimoto N, Kita T: Expression of lectinlike oxidized low-density lipoprotein receptor-I in human atherosclerotic lesions. Circulation 1999, 99:3 I I0-3 I I 7.

12. Inoue K, Arai Y, Kurihara H, Kita T, Sawamura T: Overexpression of lectin-like oxidized low-density lipoprotein receptor-I induces intramyocardial vasculopathy in apolipoprotein Enull mice. Circ Res 2005, 97:|76-184.

13. Tatsuguchi M, Furutani M, Hinagata J, Tanaka T, Furutani Y, Imamura S, Kawana M, Masaki T, Kasanuki H, Sawamura T, Matsuoka R: Oxidized LDL receptor gene (OLRI) is associated with the risk of myocardial infarction. Biochem Biophys Res Commun 2003, 303:247-250.

14. Mango R, Clementi F, Borgiani P, Forleo GB, Federici M, Contino G, Giardina E, Garza L, Fahdi IE, Lauro R, et al.: Association of single nucleotide polymorphisms in the oxidised LDL receptor I (OLRI) gene in patients with acute myocardial infarction. $J$ Med Genet 2003, 40:933-936.

15. Ohmori R, Momiyama Y, Nagano M, Taniguchi H, Egashira T, Yonemura A, Nakamura H, Kondo K, Ohsuzu F: An oxidized low-density lipoprotein receptor gene variant is inversely associated with the severity of coronary artery disease. Clin Cardiol 2004, 27:64I-644.

16. Morgan TM, Krumholz HM, Lifton RP, Spertus JA: Nonvalidation of reported genetic risk factors for acute coronary syndrome in a large-scale replication study. Jama 2007, 297: I55 I-|56I.

17. Chen Q, Reis SE, Kammerer C, Craig WY, LaPierre SE, Zimmer EL, McNamara DM, Pauly DF, Sharaf B, Holubkov R, et al.: Genetic variation in lectin-like oxidized low-density lipoprotein receptor I (LOXI) gene and the risk of coronary artery disease. Circulation 2003, I07:3|46-315I.

18. Novelli G, Borgiani P, Mango R, Lauro R, Romeo F: Further evidence that polymorphisms of the OLRI gene are associated with susceptibility to coronary artery disease and myocardial infarction. Nutr Metab Cardiovasc Dis 2007, I 7:e7-8. author reply e9-10

19. Novelli G, Borgiani P, Mango R, Romeo F, Mehta JL: OLR I gene and coronary artery disease/acute myocardial infarction: replication in an independently collected sample. Eur J Hum Genet 2006, 14:894-895. author reply 895

20. Sentinelli F, Filippi E, Fallarino M, Romeo S, Fanelli M, Buzzetti R, Berni A, Baroni MG: The 3'-UTR C>T polymorphism of the oxidized LDL-receptor I (OLRI) gene does not associate with coronary artery disease in Italian CAD patients or with the severity of coronary disease. Nutr Metab Cardiovasc Dis 2006, 1 6:345-352.

21. Trabetti E, Biscuola M, Cavallari U, Malerba G, Girelli D, Olivieri O, Martinelli N, Corrocher R, Pignatti PF: On the association of the oxidised LDL receptor I (OLRI) gene in patients with acute myocardial infarction or coronary artery disease. Eur J Hum Genet 2006, 14:127-130.

22. Chanock SJ, Manolio T, Boehnke M, Boerwinkle E, Hunter DJ, Thomas G, Hirschhorn JN, Abecasis G, Altshuler D, Bailey-Wilson JE, et al.: Replicating genotype-phenotype associations. Nature 2007 , 447:655-660

23. Hirschhorn JN, Lohmueller K, Byrne E, Hirschhorn K: A comprehensive review of genetic association studies. Genet Med 2002, 4:45-6I.

24. Hirschhorn JN, Altshuler D: Once and again-issues surrounding replication in genetic association studies. J Clin Endocrinol Metab 2002, 87:4438-444I.

25. loannidis JP, Ntzani EE, Trikalinos TA, Contopoulos-loannidis DG: Replication validity of genetic association studies. Nat Genet 2001, 29:306-309.

26. Ioannidis JP, Trikalinos TA, Ntzani EE, Contopoulos-loannidis DG: Genetic associations in large versus small studies: an empirical assessment. Lancet 2003, 36 I:567-57I.

27. Lohmueller KE, Pearce CL, Pike M, Lander ES, Hirschhorn JN: Metaanalysis of genetic association studies supports a contribution of common variants to susceptibility to common disease. Nat Genet 2003, 33:177-182.

28. Go AS, Iribarren C, Chandra M, Lathon PV, Fortmann SP, Quertermous T, Hlatky MA: Statin and beta-blocker therapy and the initial presentation of coronary heart disease. Ann Intern Med 2006, I 44:229-238.

29. Taylor-Piliae RE, Norton LC, Haskell WL, Mahbouda MH, Fair JM, Iribarren C, Hlatky MA, Go AS, Fortmann SP: Validation of a New Brief Physical Activity Survey among Men and Women Aged 60-69 Years. Am J Epidemiol 2006.

30. Iribarren C, Go AS, Husson G, Sidney S, Fair JM, Quertermous T, Hlatky MA, Fortmann SP: Metabolic syndrome and early-onset 
coronary artery disease: is the whole greater than its parts? J Am Coll Cardiol 2006, 48: 1800-I807.

31. ADVANCE web site [http://med.stanford.edu/advance/]

32. Hughes GH, Cutter G, Donahue R, Friedman GD, Hulley S, Hunkeler E, Jacobs DR Jr, Liu K, Orden S, Pirie P, et al.: Recruitment in the Coronary Artery Disease Risk Development in Young Adults (Cardia) Study. Control Clin Trials 1987, 8:68S-73S.

33. Strachan T, Read AP: Human molecular genetics 2 2nd edition. New York: Wiley-Liss; 1999.

34. Guo SW, Thompson EA: Performing the exact test of HardyWeinberg proportion for multiple alleles. Biometrics 1992, 48:361-372.

35. Pritchard JK, Stephens M, Donnelly P: Inference of population structure using multilocus genotype data. Genetics 2000, I 55:945-959.

36. Holtby S, Zahnd E, Yen W, Lordi N, McCain C, SDiSogra C: Health of California's Adults, Adolescents and Children: Findings from CHIS 200I. Los Angeles: UCLA Center for Health Policy Research; 2004.

37. Purcell S, Cherny SS, Sham PC: Genetic Power Calculator: design of linkage and association genetic mapping studies of complex traits. Bioinformatics 2003, 19:149-150.

38. White AD, Folsom AR, Chambless LE, Sharret AR, Yang K, Conwill $D$, Higgins $M$, Williams OD, Tyroler HA: Community surveillance of coronary heart disease in the Atherosclerosis Risk in Communities (ARIC) Study: methods and initial two years' experience. J Clin Epidemiol 1996, 49:223-233.

39. The Atherosclerosis Risk in Communities (ARIC) Study: design and objectives. The ARIC investigators. Am J Epidemiol 1989, I 29:687-702.

40. Volcik KA, Ballantyne CM, Coresh J, Folsom AR, Wu KK, Boerwinkle E: P-selectin Thr7I5Pro polymorphism predicts P-selectin levels but not risk of incident coronary heart disease or ischemic stroke in a cohort of 14595 participants: the Atherosclerosis Risk in Communities Study. Atherosclerosis 2006, I86:74-79.

4I. McPherson R, Pertsemlidis A, Kavaslar N, Stewart A, Roberts R, Cox DR, Hinds DA, Pennacchio LA, Tybjaerg-Hansen A, Folsom AR, et al.: A Common Allele on Chromosome 9 Associated with Coronary Heart Disease. Science 2007.

42. Volcik KA, Ballantyne CM, Coresh J, Folsom AR, Boerwinkle E: Specific P-selectin and P-selectin glycoprotein ligand-I genotypes/haplotypes are associated with risk of incident CHD and ischemic stroke: The Atherosclerosis Risk in Communities (ARIC) study. Atherosclerosis 2007.

43. Cohen JC, Boerwinkle E, Mosley TH Jr, Hobbs HH: Sequence variations in PCSK9, low LDL, and protection against coronary heart disease. N Engl J Med 2006, 354: I 264-1272.

44. Hsieh FY, Lavori PW: Sample-size calculations for the Cox proportional hazards regression model with nonbinary covariates. Control Clin Trials 2000, 2 1:552-560.

45. Hintze J: NCSS, PASS, and GESS. Kaysville: NCSS; 2006.

46. Chen $\mathrm{H}$, Li D, Saldeen T, Mehta JL: Transforming growth factorbeta(I) modulates oxidatively modified LDL-induced expression of adhesion molecules: role of LOX-I. Circ Res 2001, 89:1155-1160.

47. Mango R, Biocca S, del Vecchio F, Clementi F, Sangiuolo F, Amati F, Filareto A, Grelli S, Spitalieri P, Filesi I, et al.: In vivo and in vitro studies support that a new splicing isoform of OLRI gene is protective against acute myocardial infarction. Circ Res 2005, 97:152-158.

48. Boerwinkle E, Hixson JE, Hanis CL: Peeking under the peaks: following Up genome-wide linkage analyses. Circulation 2000, 102:1877-1878.

49. Risch N, Merikangas $\mathrm{K}$ : The future of genetic studies of complex human diseases. Science 1996, 273:1516-1517.

50. Winkelmann BR, Hager J: Genetic variation in coronary heart disease and myocardial infarction: methodological overview and clinical evidence. Pharmacogenomics 2000, 1:73-94.

5I. Botstein $D$, Risch $N$ : Discovering genotypes underlying human phenotypes: past successes for mendelian disease, future approaches for complex disease. Nat Genet 2003, 33(Suppl):228-237.

52. Tabor HK, Risch NJ, Myers RM: Opinion: Candidate-gene approaches for studying complex genetic traits: practical considerations. Nat Rev Genet 2002, 3:391-397.
53. Arnett DK, Baird AE, Barkley RA, Basson CT, Boerwinkle E, Ganesh SK, Herrington DM, Hong Y, Jaquish C, McDermott DA, O'Donnell C): Relevance of genetics and genomics for prevention and treatment of cardiovascular disease: a scientific statement from the American Heart Association Council on Epidemiology and Prevention, the Stroke Council, and the Functional Genomics and Translational Biology Interdisciplinary Working Group. Circulation 2007, I I 5:2878-290 I.

54. Marenberg ME, Risch N, Berkman LF, Floderus B, de Faire $U$ Genetic susceptibility to death from coronary heart disease in a study of twins. N Engl J Med 1994, 330: 104I-1046.

55. Carlson CS, Eberle MA, Rieder MJ, Yi Q, Kruglyak L, Nickerson DA Selecting a maximally informative set of single-nucleotide polymorphisms for association analyses using linkage disequilibrium. Am J Hum Genet 2004, 74: I06-I 20.

56. Kraus W: Genetic approaches for the investigation of genes associated with coronary heart disease. American Heart Journal 2000, 140:27-35.

\section{Pre-publication history}

The pre-publication history for this paper can be accessed here:

http://www.biomedcentral.com/1471-2350/9/23/prepub

Publish with Biomed Central and every scientist can read your work free of charge

"BioMed Central will be the most significant development for disseminating the results of biomedical research in our lifetime. "

Sir Paul Nurse, Cancer Research UK

Your research papers will be:

- available free of charge to the entire biomedical community

- peer reviewed and published immediately upon acceptance

- cited in PubMed and archived on PubMed Central

- yours - you keep the copyright

Submit your manuscript here:

http://www.biomedcentral.com/info/publishing_adv.asp
BioMedcentral 